SAINS TANAH - Journal of Soil Science and Agroclimatology

Journal homepage: http://jurnal.uns.ac.id/tanah

\title{
Tin mining process and its effects on soils in Bangka Belitung Islands Province, Indonesia
}

\author{
Sukarman $^{1 *}$, Rachmat Abdul Gani ${ }^{1}$, Asmarhansyah ${ }^{2}$ \\ ${ }^{1}$ Indonesian Center for Agricultural Land Resource Research and Development (ICALRRD), Indonesia \\ ${ }^{2}$ Indonesian Soil Research Institute (ISRI), Indonesia
}

\begin{tabular}{|c|c|}
\hline ARTICLE INFO & ABSTRACT \\
\hline Keywords: & Tin mining in the Bangka Belitung Islands Province is conducted with an open-pit mining \\
\hline Bangka Belitung Islands & system. This paper discusses the process of tin mining and its effects on soil properties in \\
\hline Ex-mine lands & this region. Tin mining led to the formation of accumulations in the form of (1) mixed soils \\
\hline Mixed soils & from horizons $A, B$, and $C,(2)$ excavated materials from the deeper levels of the pit, (3) \\
\hline Soil characteristics & $\begin{array}{l}\text { coarse-grained tailings with quartz as a primary element, }(4) \text { tailings mixed with excavated } \\
\text { soils, and (5) voids filled with water. After tin mining ended, the area was left with waste }\end{array}$ \\
\hline Article history & excavated materials, stockpiles of excavated materials or tailings, and voids, spread over \\
\hline Submitted: 2019-12-04 & an area of 124,838 ha. Overall, mining has led to significant and alarming damages to the \\
\hline Accepted: $2020-12-11$ & $\begin{array}{l}\text { biophysical aspects of land resources and the environment. This damage includes the } \\
\text { deterioration of soil structure, changes in soil texture, loss of soil organic matter, and loss }\end{array}$ \\
\hline * Corresponding Author & of soil fertility. The mining activities also caused the loss of a number of types of biota that \\
\hline $\begin{array}{l}\text { Email address: } \\
\text { sukarmandr@yahoo.co.id }\end{array}$ & $\begin{array}{l}\text { are important to provide environmental services such as the provision of forest products, } \\
\text { soil stability, maintaining the hydrological cycle, and carbon sequestration. }\end{array}$ \\
\hline
\end{tabular}

How to Cite: Sukarman, Gani, R. A., Asmarhansyah. (2020). Tin mining process and its effects on soils in Bangka Belitung Islands Province, Indonesia. Sains Tanah Journal of Soil Science and Agroclimatology, 17(2): 180-189 (doi: 10.20961/stjssa.v17i2.37606)

\section{Introduction}

In recent years, the production of Indonesian mining commodities such as tin, copper, nickel, gold, and coal has contributed greatly to the national economy. The Non-Tax State Revenues from the mining, mineral, and coal sectors reached IDR 41.17 trillion in 2018 (Mahulauw et al., 2019). Nurtjahya et al. (2017) reported that tin mining activities in the Bangka Belitung Islands not only improved community welfare but also lessened social conflicts among communities. These activities have additional positive impacts consisting of direct benefits, indirect benefits, and induced benefits (Sulistia, 2019).

Aside from the significant economic benefits, this industry also creates damage to biophysical properties of land resources, which is of great concern. Mining activities generally disassemble and distort various components within and above land resources, such as landscapes, soil structures, water systems, and all types of biota, which also function to provide environmental services such as forest products, soil stability, hydrological cycle stability, and carbon binding. (Sulistia, 2019) reported net social costs and impacts from environmental damages due to illegal unconventional onshore tin mining, including landscape changes and unusable river water. Nurtjahya et al. (2017) noted that offshore mining reduced water quality and changed biodiversity.

The activity of open-pit mining generally destroys the layers of overlying soil (rooting zone), although these zones are essential for agricultural production. Areas downstream, and even the sea, are also significantly affected due to erosion at the sides of the pit, landslides, sedimentation, and dangerous materials and wastes from the mine (Subardja et al., 2016; Sukarman \& Husnain, 2016). The Bangka Belitung Islands Province contains extensive land areas that were formerly mined. This province located at $104^{\circ} 50^{\prime}$ to $109^{\circ} 30^{\prime}$ East longitude and $0^{\circ} 50^{\prime}$ to $4^{\circ} 10^{\prime}$ South latitude, has a land area of approximately $16,424.23 \mathrm{~km}^{2}$. The area is divided into six regencies and one city, namely Bangka Regency, West Bangka Regency, Central Bangka Regency, South Bangka Regency, Belitung Regency, East Belitung Regency, and Pangkalpinang City (Statistik, 2018). The total area of exmining land in the seven districts is 124,838 ha, including an area of 12,147 ha of covered voids (Table 1 ). 
Table 1. The area of ex-mining land and voids in the Bangka Belitung Islands Province (Sukarman \& Gani, 2017)

\begin{tabular}{|c|c|c|c|}
\hline No. & Regencies & Ex-mining area (ha) & Voids area (ha) \\
\hline 1. & West Bangka & 15,083 & 1,508 \\
\hline 2. & Bangka and Pangkal Pinang City & 26,523 & 3,080 \\
\hline 3. & Central Bangka & 18,069 & 1,968 \\
\hline 4. & South Bangka & 19,488 & 2,431 \\
\hline \multicolumn{2}{|r|}{ Subtotal } & 79,163 & 8,987 \\
\hline 5. & Belitung & 15,501 & 1,491 \\
\hline & East Belitung & 30,174 & 1,669 \\
\hline \multicolumn{2}{|c|}{ Subtotal } & 45,675 & 3,160 \\
\hline \multicolumn{2}{|c|}{ Total area } & 124,838 & 12,147 \\
\hline
\end{tabular}

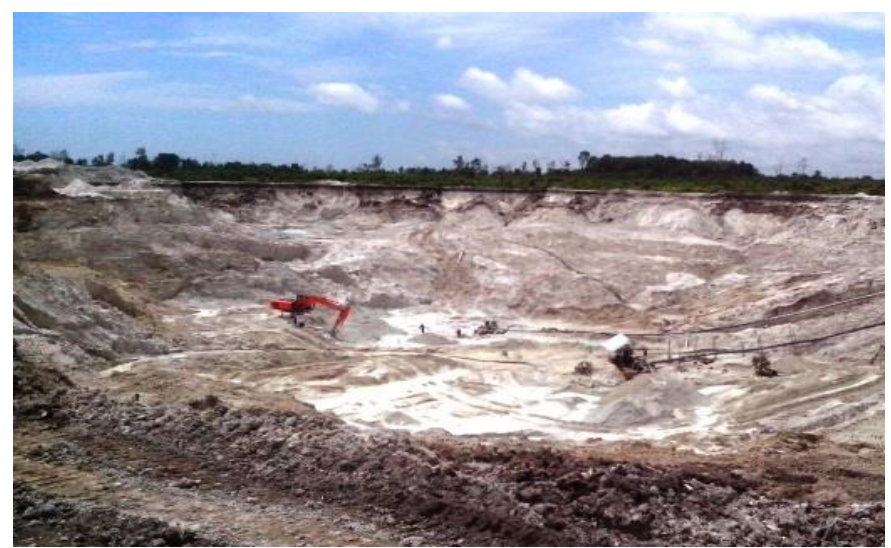

Figure 1. Stripping of the top layer of soil and excavation of kaksa

The majority of the ex-mining lands in these seven districts are already suffering very heavy damage and degradation of the physical, chemical, and biological soil properties. The degradation of soil physical properties includes the destruction of soil structures (through soil removal or production of a massive structure) and coarsening of soil texture. Often soil chemical properties such as soil nutrient content are classified as very low, such that the soil cannot support optimal plant growth (Sukarman et al., 2016).

This paper aims to: (1) discuss and provide information about the tin mining process, (2) describe the condition of exmining land, and (3) provide information on soil properties after tin mining and its continuing effect on soils.

\section{Tin Mining Process}

Exploration activities carried out by PT. Timah, one of the tin mining companies in the Bangka Belitung Islands, in search of primary tin deposits uses a geological, petrological, and geochemical structure approach. Exploration activities also include the approach of prospecting for rock sources as parent materials, valley prospecting, and tracing the existence of gravel deposits (gravel prospecting). This type of exploration has been practiced for years and continues to be used today. Sedimentation environment (facies), sequential mineralization, and sequential stratigraphy are also used for additional information and development (PT. Timah, 2019).

Tin mining in the Bangka Belitung Islands is carried out on land (onshore) and at sea (offshore). This paper discusses onshore mining. According to Dariah et al. (2010), tin mining on the Bangka Belitung Islands uses open cast mining with spray mining and pontoon suction dredge mining. Spray mining techniques can be used in large mines, small mines, and mechanical mines (Asmarhansyah \& Hasan, 2018).

Onshore mining activities affecting the environment consist of four main types, namely: (1) stripping the topsoil, (2) disposing of stripped material, (3) making dams (voids), and (4) washing (leaching) and disposal of tailings. According to (Adhiyatama, 2014), the first stage carried out in the process of tin mining for large companies is the removal of overburden above the layer of kaksa (sand containing tin). This stripping of overburden is necessary to be able to take the tin ore/forcible that is in the overburden layer. After this cover is transported, it is then placed in a mineral dump, hereinafter referred to as overburden. As a result of this process, all vegetation on the stripped soil is lost, leaving a layer of parent materials or rocks that cannot be used for planting. The overburden consists of a mixture of topsoils ( $A$ horizon) and subsoils (B horizon) and is often mixed with parent materials $(C)$ or rocks $(R)$. The second stage is the excavation of the ore layer to obtain the layers of ore from underground using heavy equipment. The pit is a workspace for extracting minerals (layers of ore). Inside the pit, a water channel must first be made which facilitates the flow of water to the reservoir, unifies the flow of water from other irregular pits, controls the flow of water to the pit, and controls excess water by directing it to the suction pipe assisted by a water pump engine. The results of this excavation leave holes filled with water, which are generally called ponds or voids. The water that fills in the voids is brown (turbid), green, or blue. Very few animals live in these water-filled voids, indicating that the water in the voids is of poor quality for aquatic life.

The next step is loading and transporting the product to the stockpile, a temporary shelter to accommodate the kaksa before it is washed (Figure 1). The dimensions of a typical stockpile are $35 \mathrm{~m} \times 15 \mathrm{~m} \times 3 \mathrm{~m}$. In the stockpile, a high-speed water spray device pressurized to 3-4 atm is used to break up the mineral deposits and split them into primary grains.

According to (Adiputra et al., 2020), the next stage of tin ore processing on Belitung Island is the washing stage. Processing activities are carried out directly in the field because the process of separating tin ore from gangue minerals is easy and does not require chemical liquids but only gravitational separation. The main processing types are jigging, sakhan, use of a lobi machine, use of a rotary dryer, and magnetic separation. Sakhan is an ore mineral concentrator that has a flat surface and works based on 
specific gravity, while a rotary dryer works by using heat flow from LPG (Liquid Petroleum Gas) combustion.

Stripping activity produces overburden materials, which consists of a mixture of topsoil and subsoil, while the process of leaching tin ore and the disposal of tailings produces quartz sand tailings and slime tailings. Sand tailing is very coarse and has no structure (loose) and is not segregated, while mud tailings consist mainly of fine-grained remnants of soil (silt and clay) and have a platey structure (Inonu, 2008).

The composition of the excavated material from former tin mining sites in Bangka Belitung is divided into four major groups: (1) upper excavated soil (topsoil), derived from an original soil made of a mixture of horizons $A, B$, and $C,(2)$ excavated soil from the lower part of $C$ horizon, (3) tailings in the form of quartz sand resulting from the leaching process/tin ore processing, and (4) a mixture of tailings and excavated bottom soil.

The compositional characteristics of the four mining waste materials show that the mined tailings have the worst properties for plant growth, as they are coarse textured with very low plant nutrient content, followed by a mixture of tailings and excavated bottom soil. The excavated soil material with the best characteristics for plant growth is topsoil characterized by a moderate to slightly coarse texture, which has the highest content of organic carbon and plant nutrients compared to other bottom soils, although these are still relatively low or very low (Sukarman \& Gani, 2017).

One of the most common tin mining activities is mining with simple tools, creating what is called an unconventional mine (TI). This activity is found in almost all Bangka Belitung regencies, originating from the local government policy to help the community during the economic crisis of the late 1990s (Pirwanda \& Pirngadie, 2015). Since then, there has been a surge not only in the number of TI miners but also in TI mining activities in the company's Revocation of Mining Business License areas, which operate without the approval of the tin mining company. According to Yunianto (2009), uncontrolled TI mining activities are caused by the issuance of the Minister of Industry and Trade in the export sector, followed by mining and processing regulations at the regency/city level, which was only oriented towards Local Own-source Revenue.

According to Asmarhansyah \& Hasan (2018), there are more than 10,000 conventional mines in the Bangka Belitung Islands Province, employing more than 50,000 people. This number is far greater than the number of small-scale mines operated by residents as business partner companies in 2010, which numbered around 3,600 groups employing around 17,000 people (Asmarhansyah \& Hasan, 2018). Mining activities that are commonly carried out by the community have been found to have a variety of adverse effects on human life and the environment. Activities which in principle are human efforts to be able to live comfortably and support families have caused humans to take actions that degrade their environment. As a result, there is a shift in the balance in the environment from its original form to a new form that is less economically and biologically productive and more hazardous to health. The most important of the many causes of pollution in the environment is solid or liquid wastes (Prianto \& Husnah, 2017).

\section{Landscape of Ex-Mining Lands}

Landscapes of ex-mining land areas are usually irregular, with many steep-walled holes. Mounds of sand tailings with poor physical, chemical, and biological soil properties are also scattered around the landscape. Small lakes are filled with water (ponds/voids) as a result of dredging sand and rocks. Land that originally functioned as productive land becomes unproductive and potentially susceptible to landslides. Land under these conditions is unable to supply an ideal medium for the growth and production of crops (Asmarhansyah, 2016). Such landscapes are often seen on former tin mining lands in the Bangka Belitung Islands Province.

Tin mining in the Bangka Belitung Islands Province uses an open cast mining method. Before mining activities took place, shrubs, agricultural land, and forests with diverse vegetationcovered these lands. Most of the land before being mined was flat to undulating in topography (Dariah et al., 2010). According to Sukarman \& Gani (2017), the existence of an open-pit mining system in the Bangka Belitung Islands Province has impacts that include:

1. Holes filled with water of different colors (brown, green, blue, and clear), commonly called voids. The length or width varies from only a few meters up to 400 meters, with depths of up to 50 meters. Piles of excavated topsoil materials, which are then called topsoil, form an irregularly-shaped collection of soils. The term "topsoil" is used differently in the field of mining than in soil science. The topsoil indicated here consists of topsoil, subsoil, parent material ( $C$ horizon), and even parent material rocks.

2. Piles of excavated material from underground, which are then called overburden. These piles were of material from undulating to hilly areas. This overburden consists of soil material and parent rock, often mixed with topsoil or with tailings.

3. Piles of waste products from leaching of materials containing tin. Generally, coarse textured (sand), white, mostly in the form of quartz sand, called tailings.

4. Mining products that are usually directly transported outside the mine site.

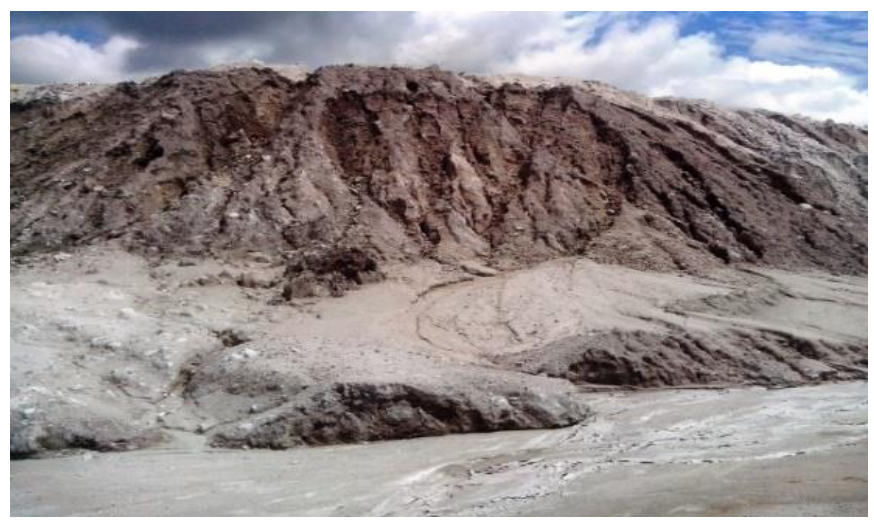

Figure 2. The condition of ex-mine quartz sand tailings and overburden piles at a mining location in Central Bangka Regency 
Table 2. The form of ex- mining lands in Bangka Belitung Islands Province (Sukarman \& Gani, 2017)

\begin{tabular}{ccccc}
\hline No. & Form of topography & Bangka Island (ha) & Belitung Island (ha) & Total Area (ha) \\
\hline 1 & Flat (0-1\%) & 22,006 & 15,309 & 37,315 \\
2 & Nearly flat (1-3\%) & 39,861 & 11,906 & 51,767 \\
3 & Undulating (3-8\%) & 9,421 & 18,460 & 27,881 \\
4 & Rolling (8-15\%) & 7,875 & - & $\mathbf{7 , 8 7 5}$ \\
\hline & Total area & $\mathbf{7 9 , 1 6 3}$ & $\mathbf{4 5 , 6 7 5}$ & $\mathbf{1 2 4 , 8 3 8}$ \\
\hline
\end{tabular}

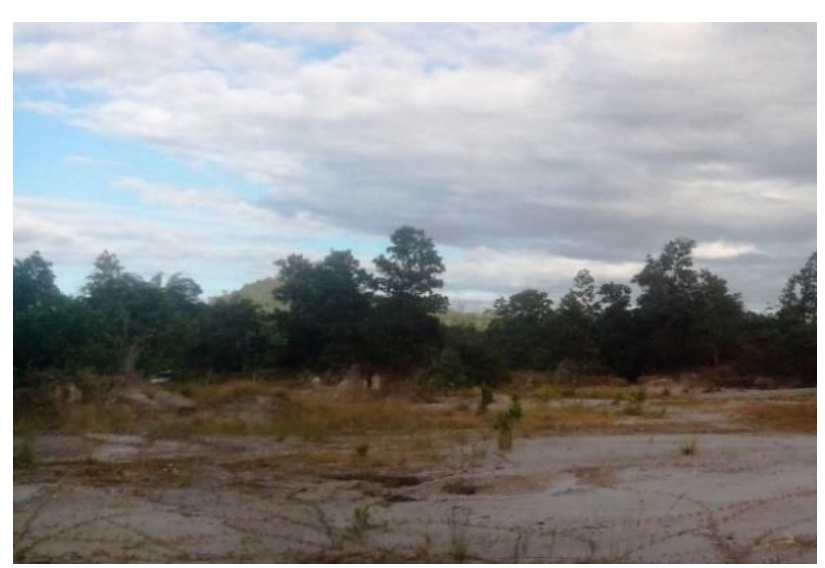

(A)

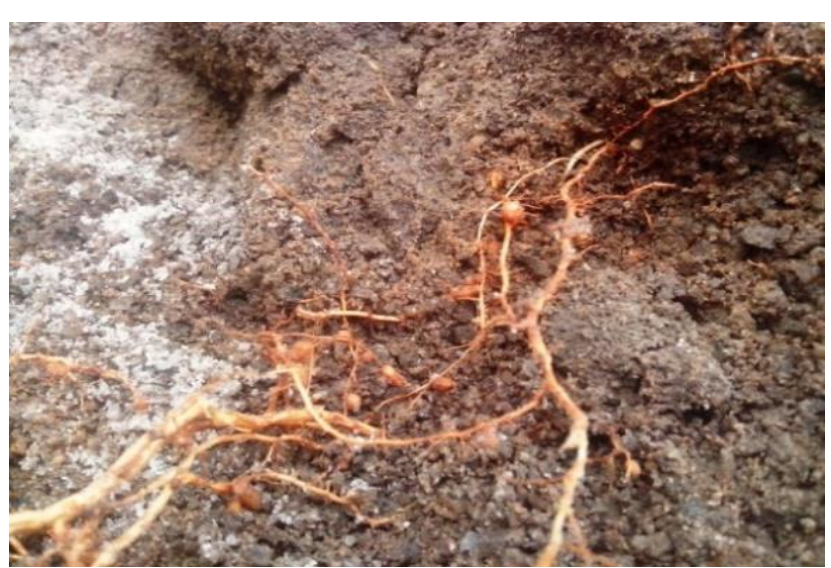

(B)

Figure 3. Acacia plants that grow at the sites of ex-mine lands (A), and the appearance of acacia root nodules (B)

Sitorus et al. (2008) found that tailings of former tin mines in Sungai Liat, Bangka, examined at four ages have poor soil physical and chemical properties. Soil acidity ranges from very acidic to acidic. Cation exchange capacity (CEC), exchangeable bases, organic $\mathrm{C}$, and total $\mathrm{N}$ are very low to low. Therefore, land rehabilitation is needed to improve the post-mining land environment, utilizing regreening through planting non-food crops, especially where there are relatively high levels of heavy metals that are dangerous for human health.

Figure 2 shows the biophysical conditions in an open-pit mining area used for tin mining in the Bangka Belitung Islands Province. These conditions are very different from the conditions of the land before it was mined. Open-pit mining activities have caused land degradation in the form of landscape damage, changes in the physical properties of the soil, mixed layers of topsoil and bottom soil, low soil organic matter content, and the exposure of toxic soil layers. Landscape damage occurs due to the excavation process to obtain underground material. The poor condition of exmining land implies the need for management strategies. Asmarhansyah (2017) offers an integrated agricultural system (IAS) implementation concept, which integrates plantings and livestock or fisheries agriculture through land preparation stages in the form of (1) adjusting the conditions of ex-mining land, (2) raising plants or livestock using innovative techniques and technology on ex-mining land, and (3) determining the sustainable market level as the goal of the production on that land. Meanwhile, Suryani (2012) put forward the concept of agroforestry for degraded lands such as ex-mining lands, namely by integrating forestry, agriculture, and livestock crops. The addition of organic matter or liming as an effort to improve the soil also must be done for the restoration of productivity to ex-mine areas (Dariah et al., 2010).

\section{Forms of Topography}

The Indonesia Center for Agricultural Land Resources Research and Development has carried out detailed soil mapping based on districts/cities of the Bangka Belitung Islands Province in 2016 (BBSDLP, 2016). This work showed that the parent material in these areas was derived from granite rocks, with original relief from an undulating to rolling topography, while mining centered on a valley where the land was flat to nearly flat (Sukarman et al., 2016).

Table 2 shows that the majority of ex-mining land has a flat or nearly flat area. This indicates that the majority of mined land has undergone smoothing, while the undulating and rolling land is mostly covered by overburden and tailings piles. Latifah (2003), in a study of land reclamation activities for former tin mines, states that over time a pile will form a wider expanse of tailings and voids, which are formed primarily by large-scale tin mining, with the voids generally becoming a lake. This will have an impact on changes to landforms at a site.

\section{Landforms}

Marsoedi et al. (1997) define landforms as the formations on the surface of the earth, especially on land, which occur due to certain geomorphic processes and through certain evolutionary processes. The condition of landforms in an area can be used to provide information on whether an area is in a pristine state or if it has undergone anthropogenic changes.

According to Sukarman \& Gani (2017), based on soil taxonomy (Soil Survey Staff, 2014), at the locations of exmining land in the Bangka Belitung Islands Province, the landforms found are no longer intact because they have been changed due to mining and are called anthropogenic landforms. 


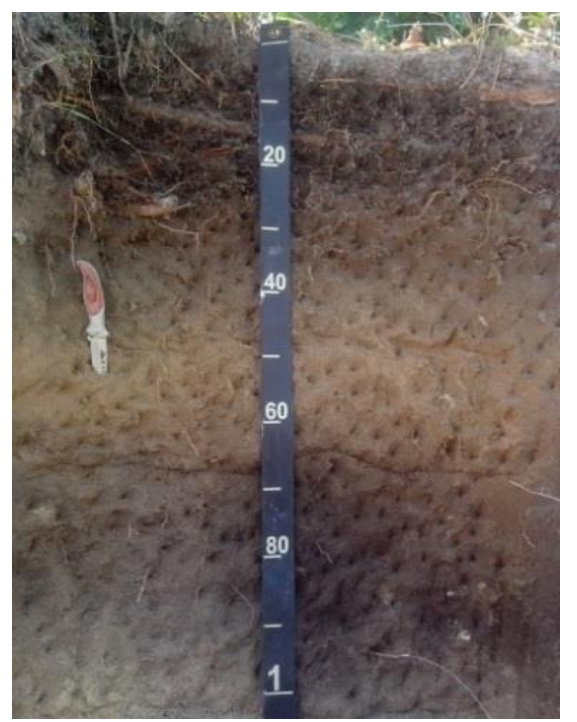

(A)

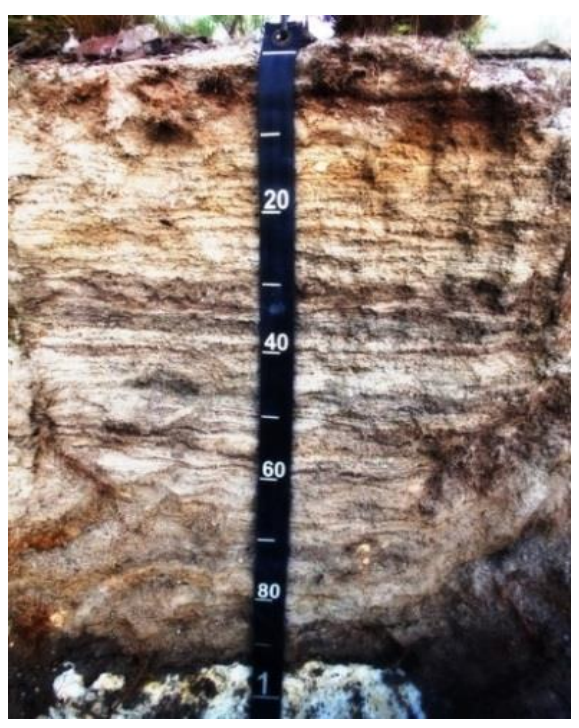

(B)

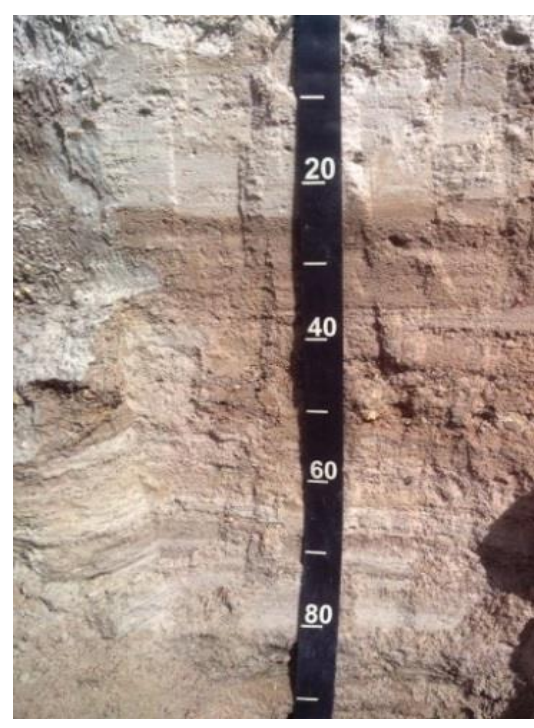

(C)

Figure 4. Soil profiles of the Dystric Cambisol original soil (A), Arenic Regosol overburden soil (B), and Quartzic Regosol tailings (C) (source: authors' documents)

Anthropogenic landforms are defined as prominent artificial landforms that can be mapped on a survey scale of 1:10,000 $-1: 25,000$. The landforms in the study location are divided into two subgroups: (1) constructional anthropogenic landforms and (2) destructional anthropogenic landforms. The tin mining activities change and decrease environmental stability (Nurtjahya et al., 2017). Latifah (2003), in the study of land reclamation activities for former tin mines, states that over time piles will form a wider expanse of tailings and voids that are formed mainly by tin mining on a large scale, with the voids generally becoming a lake. This will have an impact on changes to landforms at a site. These types of landforms can be used as a basis in planning for reforestation and rehabilitation of mining areas.

\section{Vegetation Cover}

The tin mining lands in the Bangka Belitung Islands Province are divided into three groups: (1) active mining land, (2) land that has been reclaimed, and (3) land that has not been reclaimed yet. Active mines are characterized by the presence of productive mining activities carried out by large companies with the operation of heavy equipment. Reclaimed land is usually overgrown by dense vegetation, although plants fail to grow at some sites. Unreclaimed land does not have vegetation or has little vegetation, with irregular shapes. The absence of vegetation is due to poor land quality, which does not allow plants to grow properly. In this condition, topsoil or overburden material is the part of the soil that is most easily eroded, either by direct rainfall or by uncontrolled surface runoff, due to damage to natural drainage channels. The most visible form of erosion on this ex-mine land is gully erosion.

The use of adaptive plants, based on the results of previous research, is highly recommended to obtain effective results and avoid soil losses. Some plants that are quite welladapted to grow on former tin mining areas include forestry plants such as Acacia, Paraserianthes falcataria, Melaleuca cajuputi subsp. cumingiana, and others. For plantation, agricultural, and horticultural crops, it is necessary to improve soil quality by increasing soil organic $\mathrm{C}$ as an ameliorant, requiring legume plants as cover crops. The arrangement of plants, types of commodities, and cropping patterns are also vital (Asmarhansyah, 2017). This is consistent with the findings of Narendra \& Mulyanto (2020), whose analysis of plant survival showed that, in general, plants grown on former tin mining closure land with ameliorant treatment have better survival and growth rates than plants grown on land without such treatment. This means that the addition of ameliorant materials improves the soil properties and increases the carrying capacity of the former tin mining closure land, supporting the success of land rehabilitation efforts.

According to Suprapto (2008), the problem of the lack of selection of appropriate vegetation and potential microorganisms can be overcome by selecting particular tree species and mycorrhizae suited to the specific post-mining environment. Furthermore, Hirfan (2018) in his study noted that the characteristics required of cover crops for reclaiming ex-mine lands are that they are easily planted, fast-growing and dense, symbiotic with beneficial bacteria or fungi (Rhizobium, Frankia, Azospirillum, and mycorrhizae), producing abundant biomass, and easily decomposed. One type of vegetation that can grow and adapt well is the acacia plant, which grows well and is thought to be associated with bacteria in its root nodule (Figure 3 ). The results of the study of Sitorus et al. (2008) found that tin mining on Bangka and Singkep Islands had reduced the quality of the soil and the number of natural vegetation types at the mining site compared to the number of natural vegetation types on natural soils. 
Table 3. Soil types after and before mining activities in the Bangka Belitung Islands Province

\begin{tabular}{cc}
\hline Soils after mining** & Soils before mining* \\
\hline Gleic Alluvial & Dystric Alluvial \\
Sulfidic Alluvial & Sulfic Alluvial \\
Gleic Regosol & Gleic Alluvial \\
Arenic Regosol $* *$ & Dystric Cambisol \\
Quartzic Regosol** & Dystric Cambisol \\
Dystric Regosol & Dystric Cambisol \\
\hline
\end{tabular}

*Soil classification based on National Soil Classification (Subardja et al., 2016)

**(Sukarman et al., 2016) (soil modification results)

\section{Soil Characteristics}

\subsection{Soil types}

The ex-mining lands in the Bangka Belitung Islands Province show anthropogenic changes, which have implications for the landforms and soil types. Table 3 shows soil classifications based on soil mapping in Bangka Belitung Province (BBSDLP, 2016). Soil types in unmined land are Dystric Alluvial, Gleic Alluvial, Sulfic Alluvial, and Dystric Cambisol, while ex-mine soils are Gleic Alluvial, Sulfidic Alluvial, Gleic Regosol, Arenic Regosol, Quartzic Regosol, and Dystric Regosol. The area of ex-mining land in the Bangka Belitung Islands reaches 124,838 ha, covering an area of 79,163 ha on Bangka Island and 45,675 ha on Belitung Island. Quartzic Regosols and Gleic Regosols dominate this area (Sukarman et al., 2016). Based on this result, the categories of soil in the area have changed due to the utilization and activities of tin mining lands.

The change of soil name, in the category of soil type, was a result of the mining activities, mainly due to the stripping/excavation and washing processes. The stripping process caused the $A, B$, and even $C$ horizons to disappear and form undeveloped soils, namely Dystric Regosol, while the soil in the overburden was Dystric Alluvial and Dystric Regosol. Excavation in swamplands also gave rise to pyrite layers that were previously confined to the bottom layers, so that the soil changed from Sulfic Alluvial to Sulfidic Alluvial and Gleic Regosol, while washing caused the occurrence of tailings that form coarse textured soil or Dystric Regosol, especially Arenic Regosol and Quartzic Regosol. The pyrite layer of soil contains sulfide compounds; oxidation of these compounds will produce sulfuric acid and the mineral jarosite, as well as acidity that can interfere with plant growth (Noor, 2004).

Figure 4 presents a cross section of the original soil profile around a mine area, which is compared with a transformed soil profile of former tin mining land in the Bangka Belitung Islands. The original soil type around the research location was Dystric Cambisol but has changed to Arenic Regosol and Quartzic Regosol. It is clear from the cross section of the soil profile from the ex-mining land that soil strata have been mixed between the $A, B$, and $C$ horizons.

Table 4. Average soil properties of ex-mine lands in the Bangka Belitung

\begin{tabular}{|c|c|c|c|c|c|c|c|c|}
\hline \multirow{2}{*}{ Soil Properties } & \multicolumn{2}{|c|}{ Topsoils } & \multicolumn{2}{|c|}{ Tailings } & \multirow{2}{*}{$\begin{array}{c}\text { Bottom Layer } \\
\text { Materials } \\
\text { (a) }\end{array}$} & \multicolumn{3}{|c|}{ Mixed soils } \\
\hline & (a) & (b) & (a) & (b) & & (a) & (c) & (d) \\
\hline Sand (\%) & 61.3 & 84.49 & 82.4 & 100 & 62.7 & 62.1 & 40 & 73 \\
\hline Silt (\%) & 10.5 & 8.25 & 5.4 & 0 & 8.9 & 9.3 & 20 & 15 \\
\hline Clay (\%) & 28.2 & 7.26 & 12.3 & 0 & 28.4 & 28.6 & 40 & 12 \\
\hline Texture & $\mathrm{SCL}$ & S & $\mathrm{S}$ & $S$ & $\mathrm{SCL}$ & $\mathrm{SCL}$ & $\mathrm{S}$ & LS \\
\hline $\mathrm{pH} \mathrm{H} \mathrm{H}_{2} \mathrm{O}$ & 4 & 4.08 & 4.9 & 4.04 & 4.8 & 4.5 & 5.4 & 4.8 \\
\hline C-Organic (\%) & 1.85 & 1.3 & 0.16 & 0.1 & 0.12 & 0.66 & 1.1 & 1.17 \\
\hline Total $P_{2} O_{5}(m g / 100 g)$ & 8.6 & - & 3.8 & - & 3.6 & 5.66 & 50 & 7.7 \\
\hline Total $K_{2} O(m g / 100 g)$ & 5 & - & 1.03 & - & 1.8 & 2.75 & 30 & 2 \\
\hline $\mathrm{P}_{2} \mathrm{O}_{5}$ Bray I (ppm) & 18.8 & 29.55 & 5.26 & 0.45 & 1.4 & 8.66 & 8.7 & - \\
\hline Bases $(\mathrm{cmol} / 100 \mathrm{~g})$ & 0.6 & - & 0.35 & - & 1.05 & 0.85 & 0.1 & \\
\hline Cation exc. $(\mathrm{cmol} / 100 \mathrm{~g})$ & 6.95 & 0.13 & 2.48 & 0.06 & 3.83 & 4.58 & 1.58 & 8.16 \\
\hline Base sat. & 35 & - & 10 & - & 33 & 18 & 9.6 & 17 \\
\hline $\mathrm{Cu}(p p m)$ & 0.65 & - & 0.54 & - & 0.58 & 0.49 & - & - \\
\hline$P b(p p m)$ & 7.59 & - & 9.99 & - & 16.91 & 7.61 & - & - \\
\hline$C d(p p m)$ & ud & - & ud & - & 0.09 & ud & - & - \\
\hline $\mathrm{Hg}(p p m)$ & ud & - & 0.19 & - & 0.82 & ud & - & - \\
\hline
\end{tabular}

Remarks: Description: $\mathrm{SCL}$ = sandy clay loam, LS = loamy sand, $\mathrm{S}=$ sand, ud = undetectable; Source : (a) Sukarman \& Gani (2017), (b) Asmarhansyah (2016), (c) Budianta et al. (2014), (d) Dariah et al. (2010) 


\subsection{Soil morphology characteristics}

Sukarman \& Gani (2017) stated that the soil morphology of the topsoil on former tin mine land in Bangka and Belitung Islands is relatively better and remains finer than other layers; it still shows evidence of the original structure, namely an angular or angular blocky structure. Coarse material consists of gravel and makes up less than 5 percent of the soil. Tailings are poor soil material because they are sandy, unstructured (loose), with between 20-30 percent coarse material. The bottom soils, besides having the highest content of coarse materials, also have a massive structure with very low soil fertility. This shows that the morphological and chemical properties of the ex-mine lands have been damaged or degraded. Such soil conditions are often unable to optimally support plant growth. Therefore, to restore optimal soil characteristics for growth, rehabilitation, and reclamation efforts are needed, including efforts to improve the physical, chemical, and biological nature of the soil.

Hamid et al. (2019), in a study of former tin mine land, concluded that some physical and chemical properties of soil can be improved, and showed improved clay content in the soil texture, which was originally $100 \%$ sand, with the texture class changing from sand to sandy loam and sandy clay loam with increased clay content, and decreasing the weight of the soil content from 0.34 to $0.295 \mathrm{~g} \cdot \mathrm{cm}^{-2}$ and $0.31 \mathrm{~g} \cdot \mathrm{cm}^{-2}$. Increased soil organic carbon content was still very low. The provision of organic material, in addition to improving the physical and chemical properties of the soil, also improves the biological properties of the soil. This condition also provides increased opportunities for landslides to occur.

\subsection{Soil fertility and heavy metal content}

Table 4 shows the properties of soil horizons on ex-mine lands on the Bangka Belitung Islands. The overall degradation in soil chemical properties has been reported by (Asmarhansyah, 2016; Budianta et al., 2014; Dariah et al., 2010; Sukarman \& Gani, 2017), shown in Table 4. The relatively less-degraded part of the excavated land is covered by topsoil characterized by a medium to slightly coarse texture, with the highest organic $\mathrm{C}$ content and plant nutrients measured, although it is still relatively low or very low in these. It should be stated that the topsoils here are not upper soil horizons but a mixture of topsoils, subsoils, and $C$ horizons.

The tailings from the ex-mine land require the most attention because, according to some results of research in Bangka Belitung Islands Province by Asmarhansyah (2015), tailings are the mine wastes that present the most environmental problems and are not suitable for agriculture. Also, research results from Hamid et al. (2019) showed improvement in soil chemical properties: total $\mathrm{N}$ increased but was still in the very low category, CEC increased but remained in a low category, and available $P$ increased from very low to moderate and high, but this effort was unable to improve the soil $\mathrm{pH}$, which was still classified as very acidic. Therefore, in reclamation and rehabilitation efforts, suitable plants must be carefully chosen to plant on land allocated for reforestation.
The main issue is the presence of heavy metal content contained in ex-mining land as well as in crop yields, including $\mathrm{Cu}, \mathrm{Pb}, \mathrm{Cd}$, and $\mathrm{Hg}$. Research conducted by Asmarhansyah (2015) and by Sukarman \& Gani (2017) on ex-mining lands on Bangka Island gave similar results, showing that the topsoil contained $\mathrm{Cu}$ and $\mathrm{Pb}$, while $\mathrm{Cd}$ and $\mathrm{Hg}$ were not found. The excavated soil containing the highest levels of heavy metals was excavation material from the bottom of the pits. However, the contents of the four heavy metals were still classified as very low and within tolerable limits. It was also found that heavy metals ( $\mathrm{Mn}, \mathrm{Cu}, \mathrm{Zn}, \mathrm{Sn}$, and $\mathrm{Pb}$ ) in rice crops planted on ex-mine land in Central Bangka were still below the maximum concentration allowed for rice, so rice grown on ex-mine land is safe for consumption (Asmarhansyah, 2012).

In terms of utilization, the topsoil is the best soil layer and may potentially be used for growing crops. According to Dariah et al. (2010), requirements in treating topsoils are (a) avoiding mixing of subsoils containing toxic elements or compounds, such as pyrite or acid sulfate soils, with topsoils, by recognizing the properties of the soil layers before excavation is carried out; (b) excavating topsoils to layers that meet the requirements for plant growth; (c) placing plants on topsoils in areas that are safe from erosion and stockpiling of other minerals; (d) planting fast-growing legumes on topsoils to prevent erosion and maintain soil fertility.

\section{Plant Nutrition Reserves}

The sand fraction reflects nutrient reserves in the soil; the composition of primary minerals is important for soil management for agriculture. Soils with highly weathered mineral content will also have high nutrient source reserves, while the dominance of weathering resistant minerals indicates poor nutrient reserves in the soil. The composition and association of several types of primary minerals can be used as indicators of nutrient source reserves in the soil. All soil samples from several ex-mining land locations were found to be dominated by weathered resistant minerals consisting of opaques (1-20\%), zircon (1-17\%), turbid quartz (34-84\%), clear quartz (10-31\%), iron (1-5\%), and limonite (1\%) concretions. Other sand fraction minerals sometimes found in trace amounts are andesine, green hornblende, olivine, epidote, and tourmaline (Sukarman \& Gani, 2017). The dominance of quartz sand minerals is an indicator of soils on ex-mining land (tailings) that are not ideal for plant growth and yield (Asmarhansyah, 2015).

Opaque minerals are primary minerals, including magnetite and ilmenite, which are dark metallic in color and belong to the group of resistant minerals (weathered and hard), so they often dominate the composition of primary minerals in soils that developed after mining. Similar to opaque minerals, quartz is a type of primary mineral that is often found in ex-mining land. This mineral is highly stable and resists weathering. Sources of quartz minerals on ex-mine lands are derived from biotite, granodiorite, and granite rocks (Baharudin \& Sidarto, 1995; Mangga \& Jamal, 1994; Margono et al., 1995). From the mineral composition of the sand fraction, it can be concluded that nutrient reserves in ex- 
mining land in the Bangka Belitung Islands Province are very low.

Andesine, a mineral belonging to the feldspar group, is a weatherable mineral found in very small concentrations in exmining soils. The feldspar group of minerals comprises weathered primary minerals that contain high amounts of $\mathrm{Na}+\mathrm{Ca}+, \mathrm{K}+$, and sometimes $\mathrm{Ba} 2+$. Other weathered minerals that are sometimes found are green hornblende, olivine, and tourmaline, which are called ferromagnesian minerals and are mineral sources of $\mathrm{Ca}, \mathrm{Mg}$, and $\mathrm{Fe}$ in the soil.

One of the efforts to overcome the problem of soil fertility on degraded land like ex-mine land is through the provision of a soil conditioner (Dariah et al., 2010). A soil conditioner as a soil amendment is needed to improve the quality of soil fertility in ex-mining land. Asmarhansyah (2016) concluded that the application of organic material from chicken and cattle manure on former tin mining land can increase soil fertility due to an increase in soil $\mathrm{pH}$ and nutrient availability, especially available $\mathrm{P}$ and $\mathrm{K}$ content and alkaline cations.

\section{Ex-Mine Land Reclamation}

Haryadi \& Salfutra (2018), in their study of tin mining reclamation responsibility in the Bangka Belitung Islands, stated there are several obstacles to land reclamation, such as the resumption of mining on ex-mine land by the community, reclaimed land which has not yet been economically promising for the community, difficulties because the land is no longer fertile, and others. Soils at an excavated tin mine contain heavy metals, making it difficult for the community to use the land directly, so the community must be educated in the safe use of former tin mining land (Meizilia \& Darsiharjo, 2017). Efforts to return ex-mining land in the Bangka Belitung Islands Province to its original function through reclamation have been carried out by PT. Timah as the main holder of mining concessions. Reclamation activities on ex-mining land have been carried that show soil quality improvements occurring in most of the physical and chemical properties of the soil, such as the increased level of clay content in soil texture and decreased composition of sand fraction, improvement of the soil structure, greater soil density, and higher C-organic content, total N, soil CEC, and changes in available P. Hamid et al. (2019) found that reclamation activities on former tin mining land have improved the quality of the land, namely by the improvement of several physical and chemical properties of the soil. However, these efforts have not produced all expected results: the content of $\mathrm{C}$-organic is still very low, available $\mathrm{P}$ is still relatively low, and the soil $\mathrm{pH}$ is still classified as strongly acidic. Therefore, the reclamation of ex-mining land must be carried out continuously and followed by other restoration efforts, specifically the improvement of the physical and chemical properties of the soil by providing organic material and maintaining existing vegetation.

To restore the function of ex-mining land to its original condition so that land can be used as agricultural land, a method of quality assessment is needed. Some research results indicate that soil quality indexes for these purposes provide good results, are easy to implement, and are easily understood by users. Evaluation of post-mining soil quality should be carried out before reclamation to determine soil properties that should be prioritized so that the reclamation treatment is more directed and measurable, and during reclamation to monitor the direction of the changes that occur (Rachman et al., 2017). The selection of key indicators and their threshold values, at which boundaries the soil can function optimally, greatly determines the accuracy of the soil quality index. Scoring and weighting are carried out on each key indicator; these indicators are then integrated to obtain a quality index value. Suggested key indicators for evaluating soil quality on ex-mine land are organic matter content, soil chemistry $(\mathrm{pH})$, soil content weight, available water capacity, soil aggregation, and respiration, but other indicators can be added according to the evaluation objectives and geographical conditions of the land to be evaluated.

Latief et al. (2020), in a review of ex-mining land reclamation, concluded that revegetation of tin tailings land could be done using a legume cover crop that also functions as phytoremediation, such as Leucaena leucocephala, Indigofera tinctoria, Gliricidia sepium, Calliandra harrisii, sorghum, and grass.) Meizilia \& Darsiharjo (2017) concluded that the problem of environmental damage caused by tin excavation, especially on a "kolong" (pit area), can be overcome with Eichornia crassipes, which can absorb $\mathrm{Pb}$ and $\mathrm{Cd}$ metal content in the bottom soils.

\section{Conclusion}

Bangka Belitung Islands Province has an ex-mine area of 124,838 ha, including a void area of 12,147 ha. The tin mining process has transformed the landscape into irregular landforms and voids, with loss of vegetation on the land, producing harmful effects on the condition of natural resources and the environment. Types of damage to soil resources include the mixing of top and bottom soil layers, decreased organic matter content, damage to soil structure, changes in coarse and quartz soil texture, very low soil fertility, the emergence of pyrite material, and addition of heavy metals to the soil surface. The mineral sand fraction is dominated by resistant minerals because the soil in the Bangka Belitung mining area has developed from granite parent materials. Ex-mine land consists of human-altered soils (anthropogenic soils), thus changing the classification of the soils in the soil group category. Extended reclamation efforts are needed. Key indicators for evaluating soil quality on ex-mine land are suggested as follows: organic matter content, soil chemistry $(\mathrm{pH})$, soil content weight, available water capacity, aggregation, and soil respiration.

\section{Declaration of Competing Interest}

The authors declare no competing financial or personal interests that may appear and influence the work reported in this paper.

\section{References}

Adhiyatama, S. (2014). Proses penambangan timah alluvial pada tambang besar Nudur Hilir PT. Timah (Persero) Tbk, Kabupaten Bangka Selatan, Provinsi Bangka 
Belitung. Jurusan Teknik Pertambangan Fakultas Teknologi Industri, Universitas Muslim Indonesia.

Adiputra, R. N., Agustin, F., Sulastri, A., Abdullah, C. I., Nugraha, I., Andriansyah, R., \& Hadiprayitno, M. (2020). The tin ore separation process and optimizing the rare earth mineral (monazite) as a by-product of tin mining in East Belitung Regency. IOP Conference Series: Earth and Environmental Science, 413(1), 12004.

Asmarhansyah. (2015). Characteristic of physical and chemical properties of former-tin mining areas for crop production in Bangka Island. Prosiding Nasional Sistem Informasi Dan Pemetaan Sumberdaya Lahan Mendukung Swasembada Pangan, 181-190.

Asmarhansyah. (2017). Inovasi teknologi untuk peningkatan produktivitas lahan bekas tambang timah. Jurnal Sumberdaya Lahan, 11 (2), 91-106.

Asmarhansyah, A. (2016). Improving Soil Properties and Yield of Corn (Zea Mays L.) by Application of Organic Amendment on Abandoned Tin-Mining Land in Bangka Island. Journal of Tropical Soils, 21(3), 140689.

Asmarhansyah, \& Hasan, R. (2018). Reklamasi lahan bekas tambang timah berpotensi sebagai lahan pertanian di Kepulauan Bangka Belitung. Jurnal Sumberdaya Lahan, 12 (2), 73-82.

Asmarhansyah, S. D. (2012). Perbaikan kualitas lahan bekas tambang timah Bangka Tengah melalui penggunaan tanah mineral dan pupuk organik. Prosiding Seminar Nasional Teknologi Pemupukan Dan Pemulihan Lahan Terdegradasi.325-336.

Baharuddin., \& Sidarto. (1995). Peta Geologi Lembar Belitung, Sumatera 1:250,000 = Geological Map of the Belitung Sheet, Sumatera. Pusat Penelitian dan Pengembangan Geologi.

BBSDLP. (2016). Peta Tanah Semidetail (skala 1: 50.000) Kabupaten se Provinsi Kepulauan Bangka Belitung. Balai Besar Litbang Sumberdaya Lahan Pertanian, Badan Litbang Pertanian. Bogor.

Budianta, D., Gofar, N., \& Andika, G. A. (2014). Improvement of sand tailing fertility derived from post tin mining using leguminous crop applied by compost and mineral soil. Journal of Tropical Soils, 18(3).

Dariah, A., Abdurachman, A., \& Subardja, D. (2010). Reklamasi lahan eks-penambangan untuk perluasan areal pertanian. Jurnal Sumberdaya Lahan, 4(1), 1-12.

Hamid, I., Priatna, S. J., \& Hermawan, A. (2019). Karakteristik beberapa sifat fisika dan kimia tanah pada lahan bekas tambang timah. Jurnal Penelitian Sains, 19(1), 23-31.

Haryadi, D., \& Salfutra, R. D. (2018). Integrative Law Enforcement about Tin Mining Reclamation Responsibility at Bangka Belitung Island. E3S Web of Conferences, 68, 3017.

Hirfan, H. (2018). STRATEGI REKLAMASI LAHAN PASCA TAMBANG. PENA TEKNIK: Jurnal IImiah IImu-IImu Teknik, 1(1), 101-108.

Inonu, I. (2008). Pengelolaan lahan tailing timah di pulau Bangka: penelitian yang telah dilakukan dan prospek ke depan. Program Studi Agroteknologi FPPB, Universitas Bangka Belitung.
Latief, M., F., Khaerani, P., I., Iskandar, H., Syamsu, J., A., \& Akil S. (2020). Tinjauan reklamasi lahan pasca tambang timah (Sn) melalui penanaman tumbuhan pakan. PROSIDING SEMINAR NASIONAL "Membangun Sumber Daya Peternakan di Era Revolusi Industri 4.0". pp 39-47. http://www.researchgate.net/publication/341251523. Accessed at 30 October 2020.

Latifah, S. (2003). Kegiatan Reklamasi Lahan Pada Bekas Tambang. USU Digital Library, 1-17.

Mahulauw, A., Zaenal, Z., \& Toni, I. (2019). Analisis Jumlah Penggunaan Batubara dalam Negeri dan Jumlah Ekspor Batubara serta Dampaknya terhadap Pendapatan Negara Bukan Pajak pada Tahun 2018-2025. Prosiding Teknik Pertambangan Februari, 5 (1). http://karyailmiah.unisba.ac.id/index.php/pertambang an/article/view/15198. Accessed at 30 October 2020.

Mangga, S. A., \& Jamal, B. (1994). Peta geologi lembar Bangka Utara, Sumatera, Skala 1:250.000. In Badan Penelitian dan Pengembangan Geologi, Bandung.

Margono, U., Supandjono, J. B., \& Partoyo, E. (1995). Peta Geologi Lembar Bangka Selatan Skala 1:250.000. Pusat Penelitian dan Pengembangan Geologi, Badan Geologi.

Marsoedi, D. S., Widagdo, D. J., Suharta, N., Darul, S. W. P., Hardjowigeno, S., Hof, J., \& Jordans, E. R. (1997). Pedoman klasifikasi landform. Laporan Teknis, 5.

Meizilia, \& Darsiharjo. (2017). Lahan bekas tambang timah di Pulau Bangka dan Belitung, Indonesia dan kesesuaiannya untuk komoditas pertanian. Jurnal Tanah Dan Iklim Vol, 41(2), 21-33.

Narendra, B. H., \& Mulyanto, B. (2020). Soil properties improvement and use of adaptive plants for land rehabilitation of post tin mining closure in Bangka Island, Indonesia. Biodiversitas Journal of Biological Diversity, 21(2).

Noor, M. (2004). Lahan rawa: sifat dan pengelolaan tanah bermasalah sulfat masam. Divisi Buku Perguruan Tinggi, RajaGrafindo Persada.

Nurtjahya, E., Franklin, J., A., Umroh, \& Agustina F. (2017). The impact of tin mining in Bangka Belitung and its reclamation studies. Matec Web of Conferences 101, 04010. Doi: 10.1051/matecconf/201710104010.

Pirwanda, F. \& Pirngadie, B. H. (2015). Dampak kegiatan tambang timah inkonvensional terhadap perubahan guna lahan di Kabupaten Belitung. Jurnal Planologi Unpas, 2(3), 177-194.Prianto, E., \& Husnah, H. (2017). Penambangan Timah Inkonvensional: Dampaknya Terhadap Kerusakkan Biodiversitas Perairan Umum Di Pulau Bangka. BAWAL Widya Riset Perikanan Tangkap, 2(5), 193-198.

Rachman, A., Irawan, I., \& Suastika, I. W. (2017). Indikator kualitas tanah pada lahan bekas penambangan. Jurnal Sumberdaya Lahan, 11(1).

Sitorus, S. R. P., Kusumastuti, E., \& Badri, L. N. (2008). Karakteristik dan teknik rehabilitasi lahan pasca penambangan timah di Pulau Bangka dan Singkep. Jurnal Tanah Dan Iklim, 27, 57-73.

Soil Survey Staff. (2014). Kunci Taksonomi Tanah. Edisi Ketiga, 2015. In Balai Besar Penelitian dan Pengembangan Sumberdaya Lahan Pertanian. 
Statistik, B. P. (2018). Provinsi Kepulauan Bangka Belitung Dalam Angka 2017. Jakarta: BPS.

Subardja, D. S., Ritung, S., Anda, M., Sukarman, Suryani, E., \& Subandiono, R. E. (2016). Petunjuk Teknis Klasifikasi Tanah Nasional (2nd Ed.). Balai Besar Penelitian dan Pengembangan Sumberdaya Lahan Pertanian (BBSDLP). http://perpustakaan.pertanian.go.id/repository_litbang /uploaded_files/BBSDLP/Keredaksian_dan_dafisi.pdf. Accessed at 30 October 2020.

Sukarman, Anda, M., Muslihat, L., Kuntjoro, D., Iskandar, A., Murdiyati, S. R., Gani, R. A., Purwanto, S., Agian, Y., \& Risalah, N. (2016). Atlas peta tanah lahan bekas tambang tingkat semi detail provinsi Bangka Belitung. Balai Besar Penelitian Dan Pengembangan Sumberdaya Lahan Pertanian.

Sukarman, \& Gani, R. A. (2017). Lahan Bekas Tambang Timah di Pulau Bangka dan Belitung, Indonesia dan Kesesuaiannya untuk Komoditas Pertanian (Ex-mining land in Bangka and Belitung Islands, Indonesia and their suitability for agricultural commodities). Jurnal Tanah Dan Iklim, 41(2), 101-114.

Sukarman, \& Husnain. (2016). Karakteristik lahan bekas tambang dan permasalahannya di Bangka Belitung dan
Pulau Buru. Sumber Daya Lahan Dan Air, Prospek Pengembangan Dan Pengelolaan, 54-71.

Sulistia. (2019). Net social impact of illegal unconventional onshore tin mining in South Bangka, Bangka Island. International Conference on Green Energy and Environment. IOP Conf. Series: Environmental Science 353. https://doi.org/101088/1755-1315/353/1/012026

Suprapto, S. J. (2008). Tinjauan reklamasi lahan bekas tambang dan aspek konservasi bahan galian. Buletin Sumberdaya Geologi, 3 (1), 20-32.

Suryani, E. (2012). Peningkatan Produktivitas Tanah Melalui Sistem Agroforestri. Peningkatan Produktivitas Tanah Melalui Sistem Agroforestri, 6(2). https://doi.org/10.2018/jsdl.v6i2.6394

PT. Timah. (2019). http://www.timah.com/v3/ina/operasieksplorasi/. Accessed at 30 December 2019.

Yunianto, B. (2009). Kajian problema pertambangan timah di Propinsi Kepulauan Bangka Belitung sebagai masukan kebijakan pertimahan nasional. Jurnal Teknologi Mineral Dan Batubara, 5(3), 97-113. 